\title{
The effect of different sowing dates on dry matter and nitrogen dynamics for winter wheat: An experimental simulation study
}

\author{
Kaizhen Liu ${ }^{1}$, Chengxiang Zhang ${ }^{1}$, Beibei Guan ${ }^{1}$, Rui Yang ${ }^{1}$, Ke Liu $^{1}$, Zhuangzhi Wang ${ }^{1}$, Xiu Li $^{1}$, Keyin Xue $^{1}$, \\ Lijun Yin ${ }^{\text {Corresp., } 1}$, Xiaoyan Wang ${ }^{\text {Corresp. 1, } 2}$ \\ ${ }^{1}$ Agronomy College of Yangtze University, Yangtze University, Jingzhou, Hubei, China \\ 2 Engineering Research Center of Ecology and Agricultural Use of Wetland, Ministry of Education, Yangtze, Jingzhou, Hubei, China \\ Corresponding Authors: Lijun Yin, Xiaoyan Wang \\ Email address: yinlijun326@163.com, wamail_wang@163.com
}

Background: Timely sowing is an important agronomic measure to ensure the normal germination, stable seedling establishment, and yield formation for winter wheat (Triticum aestivum $L$.). Delayed sowing frequently occurs in the current multi-cropping system and mechanized production of this crop. However, the ways in which different sowing dates affect yield and its potential mechanism is still unknown in the middle-lower Yangtze River Basin. We sought to provide a theoretical basis for these mechanisms to improve regional wheat production. Methods: We investigated the wheat's yield differences in a two-year field study under different sowing dates and took into account related growth characteristics including meteorological conditions, growth period, tillers, dry matter accumulation (DMA), and nitrogen accumulation (NA). We used the logistic curve model to simulate DMA and NA dynamics of single stem wheat under different sowing dates. We then analyzed and compared wheat accumulation for different sowing dates. Results: Our results showed that grain yield declined by $0.97 \pm 0.22 \%$ with each one-day change (either early or delayed) in sowing beyond the normal sowing date. The yield loss could be explained by the inhibition of crop growth, yield components, biomass and nitrogen ( $\mathrm{N}$ ) production. The negative effects of delayed sowing were caused by environmental limitations including adverse weather factors such as low temperature during vegetative growth, shortened duration of various phases of crop development, and increased temperature during the grain-filling period. The grain yield gap decreased between the late and normal sowing periods owing to a compensatory effect between the highest average rates $\left(V_{t}\right)$ and the rapid accumulation period $(T)$ of DMA and NA for single stem wheat. The grain yield was maintained at $6,000 \mathrm{~kg} \mathrm{ha}^{-1}$ or more when the ratio of DMA at the mature-to-jointing stage $\left(M_{D} / J_{D}\right)$ and the ratio of NA at the mature-to-jointing stage 
$\left(M_{N} / J_{N}\right)$ was $4.06(P<0.01)$ and $2.49(P<0.05)$, respectively. The compensatory effect did not prevent the impact caused by delayed sowing, which caused biomass and $\mathrm{N}$ production to decrease. Physiological development reached a maximal accumulation rate $\left(T_{m}\right)$ of NA earlier than DMA. 
1 The effect of different sowing dates on dry matter and

2 nitrogen dynamics for winter wheat: An experimental

3 simulation study

4

5

6

7

8

9

10

11

12

13

14

15

16

17

18

19

20

21

22

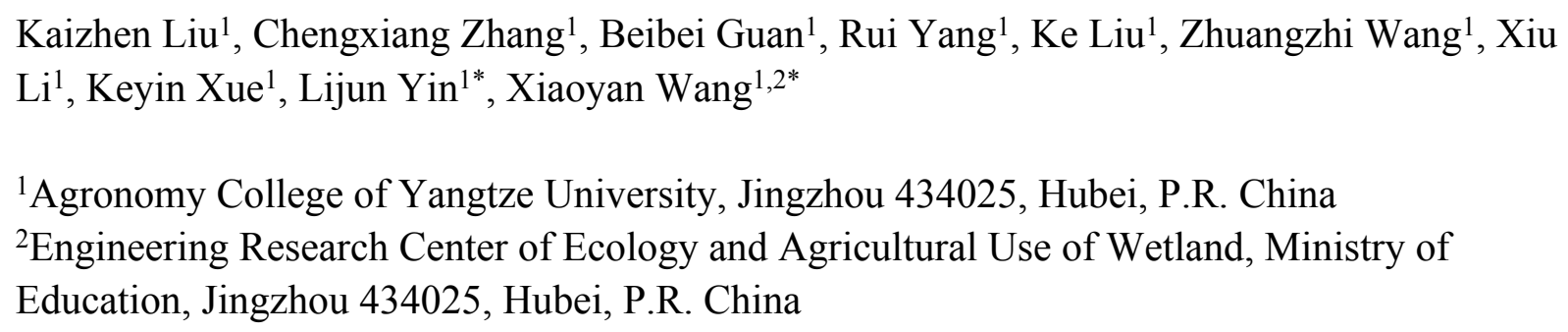

\section{Abstract}

Background: Timely sowing is an important agronomic measure to ensure the normal germination, stable seedling establishment, and yield formation for winter wheat (Triticum aestivum L.). Delayed sowing frequently occurs in the current multi-cropping system and mechanized production of this crop. However, the ways in which different sowing dates affect yield and its potential mechanism is still unknown in the middle-lower Yangtze River Basin. We sought to provide a theoretical basis for these mechanisms to improve regional wheat production. Methods: We investigated the wheat's yield differences in a two-year field study under different sowing dates and took into account related growth characteristics including meteorological conditions, growth period, tillers, dry matter accumulation (DMA), and nitrogen accumulation (NA). We used the logistic curve model to simulate DMA and NA dynamics of single stem wheat under different sowing dates. We then analyzed and compared wheat accumulation for different sowing dates.

Results: Our results showed that grain yield declined by $0.97 \pm 0.22 \%$ with each one-day change 
36 (either early or delayed) in sowing beyond the normal sowing date. The yield loss could be explained by the inhibition of crop growth, yield components, biomass and nitrogen $(\mathrm{N})$ production. The negative effects of delayed sowing were caused by environmental limitations including adverse weather factors such as low temperature during vegetative growth, shortened duration of various phases of crop development, and increased temperature during the grainfilling period. The grain yield gap decreased between the late and normal sowing periods owing to a compensatory effect between the highest average rates $\left(V_{t}\right)$ and the rapid accumulation period $(T)$ of DMA and NA for single stem wheat. The grain yield was maintained at $6,000 \mathrm{~kg}$ $\mathrm{ha}^{-1}$ or more when the ratio of DMA at the mature-to-jointing stage $\left(\mathrm{M}_{\mathrm{D}} / \mathrm{J}_{\mathrm{D}}\right)$ and the ratio of NA at the mature-to-jointing stage $\left(\mathrm{M}_{\mathrm{N}} / \mathrm{J}_{\mathrm{N}}\right)$ was $4.06(P<0.01)$ and $2.49(P<0.05)$, respectively. The compensatory effect did not prevent the impact caused by delayed sowing, which caused biomass and $\mathrm{N}$ production to decrease. Physiological development reached a maximal accumulation rate $\left(T_{m}\right)$ of NA earlier than DMA.

Wheat is one of the most widely-cultivated crops worldwide and wheat growers in China are the largest producers in the world, producing 17\% of the world's total wheat (Food and Agricultural of the United Nation, 2020). Winter wheat accounts for approximately $95 \%$ of the total (winter and spring) wheat production in China (Lu et al., 2013; Wu et al., 2014; Geng et al., 2019). The middle-lower Yangtze River Basin is one of the main winter wheat growing regions in China due to its abundance of photothermal resources necessary for the rice-wheat rotation system (Zhang et al., 2013). The practice of rice-wheat crop rotation dominates in this area (Liu et al., 2016) and its grain output is vital to ensuring food security in China.

The sowing date is one of the most important factors affecting grain production and quality (Ferrise et al., 2010). The optimum sowing date depends on rainfall and temperature (Jackson et al., 2000) to maintain high grain yields. The rice-wheat rotation system is one of the world's most predominant agricultural production systems (Gupta et al., 2003). However, there are limitations to this planting pattern. In recent years, simple cultivation methods including mechanical transplanting and direct seeding of rice have shortened the seedling period. There has been a significant yield benefit to the delayed sowing of rice. Wheat crops are planted after rice crops and the late sowing of rice impacts the sowing date for wheat as well (Xu et al., 2013).

Global warming has significantly impacted agricultural production and has been the focus of 
many researchers (Sun et al., 2015; Ding et al., 2015). Simulation studies and observed data have shown that a significant decrease in the grown duration of winter wheat may be accompanied by a significant reduction in grain yield due to the evident warming trend (He et al., 2014, 2015; Xiao et al., 2015). Global warming over recent decades has created extended growing periods prior to wheat wintering, encouraging farmers to delay the sowing date for winter wheat (Xiao et al., 2013, 2015). Studies have shown that this delay may increase, maintain, or decrease the grain yield of winter wheat (Jalota et al., 2013; Ding et al., 2015; Yin et al., 2018).

Previous research has indirectly suggested that sowing wheat late leads to poor crop conditions, even with optimal weather conditions (Tester and Langriridge, 2010). Delayed sowing exposes crops to adverse conditions such as low temperatures during vegetative growth, resulting in a low germination rate, poor tillering ability, and low plant population (Borràsgelonch et al., 2012; Fernanda et al., 2013). Late sowing delays flowering and exposes crops to high temperatures during the grain-filling stage, thus accelerating reproductive development and reducing grainfilling (Bailey-Serrees et al., 2019; Dubey et al., 2019). Late sowing also reduces dry matter and $\mathrm{N}$ accumulation in wheat crops (Ehdaie and Waines, 2001). Therefore, a delay in sowing wheat often has a negative impact on the seed germination process, tiller development, overall crop growth, and final yield (Hussain et al., 2017; Kaur, 2017). It is important to note that a delay sowing during the optimal period does not have a serious negative impact on yield, as it may improve the assimilate allocation and $\mathrm{N}$ utilization efficiency for winter wheat (Yin et al., 2018, 2019).

The formation of crop yield is determined by the accumulation and distribution of dry matter (Zheng et al., 2013). Natural and human factors such as climate, soil, and field management practices all affect the dry matter accumulation (DMA) process and ultimately lead to yield differences. Nitrogen accumulation (NA) is the main nutrient affecting the grain yield and protein concentrations (Ehdaie and Waines, 2001). DMA and NA can be described using two models: the mechanism model and the empirical model (Whisler et al., 1986). In the empirical model, the logistic growth equation (Wang et al., 2014; Jain et al., 2010; Royo et al., 1999) has certain biological significance and is widely used.

The logistic equation has been used to describe the accumulation of dry matter for winter wheat and summer maize as well as the cotton NA process (Zhao et al., 2013; Xiao et al., 2014; Du et al., 2016). The accumulation of dry matter and $\mathrm{N}$ is a continuous process that changes over time and is closely related to yield. There are significant differences seen over time and research sites. There have been few studies on the effects of the sowing date on the growth and yield of wheat 
106

107

108

109

110

111

112

113

114

115

116

117

118

119

120

121

122

123

124

125

126

127

128

129

130

131

132

133

134

135

136

137

138

in the Jianghan Plain of the middle-lower Yangtze River Basin in terms of DMA, NA, and yield.

The objectives of this study were to ( $i$ ) quantify the effect of different sowing dates on grain yield, yield components, tillers, and other agronomic traits of winter wheat, and ( ii ) utilize the logistic model to fit the DMA and NA process of winter wheat in different sowing dates. We quantitatively analyzed the growth process of wheat according to the derived quantity.

\section{Materials and methods}

\section{Experimental site}

Field experiments were conducted at the experimental farm station of Yangtze University $\left(30^{\circ} 36^{\prime} \mathrm{N}, 112^{\circ} 08^{\prime} \mathrm{E}\right)$, Jinzhou City, Hubei Province, China, during two growing seasons in $2018 / 2019$ and 2019/2020. The farm station is located in the Jianghan Plain, which is characterized as a typical subtropical monsoon climate zone in the middle-lower Yangtze River Basin of China. Two-year field experiments were performed in the nearby fields. The field chosen for this study was previously managed as a summer-rice/winter-wheat double-cropping system. The daily average temperature and precipitation during the two-year growing seasons are shown in Fig. 1. Soil samples were collected at the start of the experiments. The soil was classified as sandy loam, and the main physicochemical properties before sowing wheat in 2018 and 2019 are shown in Table 1.

\section{Experimental design and crop management}

A widely-planted winter wheat cultivar, Zhengmai 9023, was used in our field experiments.

Seeds were sown by broadcasting at a rate of $15 \mathrm{~g} \mathrm{~m}^{-2}$ in 2018 and 2019 on 28 October (early sowing), 5 November (normal sowing), 13 November (late sowing), and 21 November (latest sowing) using a manual ditching drill with $25-\mathrm{cm}$ row spacing. The plots were arranged in a completely random design with three replicates. Each plot included 25 rows with 25 -cm in-row spacing ( $2 \mathrm{~m}$ wide), $6 \mathrm{~m}$ in length. Basal fertilization of each subplot included $\mathrm{N}$ as urea, phosphorus as calcium superphosphate, and potassium as potassium chloride at rates of $90 \mathrm{~kg} \mathrm{ha}^{-}$ ${ }^{1} \mathrm{~N}, 105 \mathrm{~kg} \mathrm{ha}^{-1} \mathrm{P}_{2} \mathrm{O}_{5}$, and $105 \mathrm{~kg} \mathrm{ha}^{-1} \mathrm{~K}_{2} \mathrm{O}$, respectively. An additional $90 \mathrm{~kg} \mathrm{ha}^{-1}$ of $\mathrm{N}$ was applied at the beginning of the joint growing stage (Sun et al., 2019; Yin et al., 2020). Fields were managed following the local cultural practices. Pests, weeds, and diseases were controlled chemically.

\section{Measurement items and methods}


139

140

141

142

143

144

145

146

147

148

149

150

151

152

153

154

155

156

157

158

159

160

161

162

163

164

165

166

167

168

169

170

171

$172 W=\frac{W_{\max }}{1+a e^{-k T}}$

173

Two $0.5 \mathrm{~m}$ lines with uniform emergence were made at the three-leaf stage. These were randomly selected for fixed points in each plot. Tillers were counted before wintering and at the jointing, booting, flowering, and maturity stages in each plot with three repeats, respectively (Zhou et al., 2020).

Sampling for whole plant dry matter was conducted before wintering and at the jointing, booting, flowering, and maturity stages in each plot with three repeats at ground level. The samples were dried at $105^{\circ} \mathrm{C}$ for $30 \mathrm{~min}$ and then at $80^{\circ} \mathrm{C}$ in a fan-forced oven to a constant weight to determine the biomass (Shah et al., 2020). A sub-sample of 30 fertile shoots was separated into flag leaves, other leaves, stem sheathes, and ear tissues (glumes and grains at maturity). All separated plant material was oven-dried as described above, weighed, milled, and analyzed for total N concentration (Kjeldahl method, KDY-9820 Auto Distillation Unit, Beijing, China). NA was calculated by multiplying the $\mathrm{N}$ concentration (\%) by dry weight. The NA of the single stem was calculated as the sum of $\mathrm{N}$ absorption of the single stem in different measured organs at each growing stage. This process was repeated three times (Yin et al., 2018).

Plants used to measure yield were harvested from a sampling area $2.0 \mathrm{~m} \times 1.0 \mathrm{~m}$ (row length $\times$ row width) in each plot, using the method described by Yin et al. (2018). The grain was air-dried, weighed, and adjusted to standard 12\% moisture content. This was considered to be the grain dry matter yield. Effective panicle per unit area was measured from a sampling area $1.0 \mathrm{~m} \times 1.0 \mathrm{~m}$ (row length $\times$ row width). Thirty panicles were taken continuously to determine the grain number of the panicle. The 1,000-grain weight was air-dried, weighed, and adjusted to a standard $12 \%$ moisture content. All the above measurements were repeated three times per treatment.

The corresponding date of the main growth period of wheat was recorded in the field according to Zadok's growth scale (Karimizadeh et al., 2011) with more than 50\% of seedlings in the plot sampled. We collected the daily maximum, minimum, and average temperature, light hours, daily rainfall, and other meteorological datum during the two-year wheat growth period from the Jingzhou Meteorological Bureau of Hubei Province.

\section{Calculations and data analysis}

A logistic model was used to quantitatively describe the dynamic changes of accumulation in winter wheat shoots to model the accumulation pattern as follows (Du et al., 2016):

where, $W\left(\mathrm{~g} \mathrm{stem}^{-1}\right)$ is the accumulation in wheat, $W_{\max }\left(\mathrm{g} \mathrm{stem}^{-1}\right)$ is the theoretical maximum 
174 accumulation, $T(\mathrm{~d})$ is days after emergence, a and $\mathrm{k}$ are the constants to be found.

175 The following functions can be obtained by calculating the first, second, and third derivative of 176 formula (1), respectively.

$177 \quad T_{1}=\frac{1}{k} \ln \frac{2+\sqrt{3}}{a}$

$178 \quad T_{2}=\frac{1}{k} \ln \frac{2-\sqrt{3}}{a}$

$179 T_{m}=\frac{\ln a}{k}$

$180 V_{m}=\frac{k W_{\max }}{4}$

181 where, $T_{1}(\mathrm{~d})$ is the accumulated growth time at the fastest beginning date of growth curve, $T_{2}(\mathrm{~d})$

182 is the accumulated growth time at the termination date, maximum relative growth rate $V_{m}(\mathrm{~g}$

183 stem $\left.^{-1} \mathrm{~d}^{-1}\right)$ and its cumulative growth time $T_{m}(\mathrm{~d})$.

184 The fast accumulation phase began at $T_{1}$ and ended at $T_{2}, W$ is a linear correlation with the days 185 after emergence and the average growth rate $\left(V_{\mathrm{t}}\right)$.

$186 V_{t}=\frac{W_{2}-W_{1}}{T_{2}-T_{1}}$

187 Yield loss (\%) due to the early or late sowing was calculated as follows (Shah et al., 2020):

188 Yield loss $(\%)=\frac{Y_{n s}-Y}{Y_{n s}} \times 100$

189 where $Y_{n s}$ and $Y$ are the grain yields of normal and early or late sowing dates, respectively.

\section{Statistical analysis}

Data preparation was performed with Microsoft Excel 2010 and the final data plots were produced with Origin 8.0. Multiple comparisons were performed after a preliminary F-test. Means were tested based on the least significant difference at $P<0.05$ using Data Processing System (DPS) v.7.05 software.

Results

\section{Weather conditions and crop phenology}

The mean daily temperatures of the two wheat growing seasons first decreased and then increased (Fig. 1). The mean daily temperatures below $10^{\circ} \mathrm{C}$ lasted 89 days (for a continuous three days or longer, lower than $10^{\circ} \mathrm{C}$ ) and decreased to 77 days in the second year. The thermal time from the sowing to wintering stage decreased greatly when sowing was delayed by more 
204

205

206

207

208

209

210

211

212

213

214

215

216

217

218

219

220

221

222

223

224

225

226

227

228

229

230

231

232

233

234

235

236

237

238

239

by $21 \%, 37 \%$, and $51 \%$ for $8-, 16-$, and 24 -days delay in sowing compared with the first sowing date $(28$-Oct).

The mean daily temperatures increased gradually from flowering to the end of grain-filling when sowing was delayed by more than eight days across two experimental years. The temperatures ranged from $20.08^{\circ} \mathrm{C}$ for 28 -Oct to $20.71^{\circ} \mathrm{C}$ for $21-\mathrm{Nov}$ in $2018-2019$, and $17.93^{\circ} \mathrm{C}$ for 28 -Oct to $20.25^{\circ} \mathrm{C}$ for $21-\mathrm{Nov}$ in $2019-2020$ (Table 2). There was a significant negative correlation in the second year $(r=-0.94, P<0.05)$ between the grain filling days of each sowing date and the mean daily temperatures during the filling stage.

The crop growth cycle from seeding to the end of the grain filling period of each sowing date was significantly shortened when the sowing date was delayed in the 2018-2019 and 2019-2020 growing seasons. The growth duration of 8-, 16- and 24-days delay in sowing decreased by 7, 12 , and 18 days on average over two growing seasons when compared with the first sowing date (28-Oct). This difference was mainly due to the earlier flowering period and the compression of the grain-filling period for the late sowing date. The average flowering date moved forward by 4.0, 7.5, and 11.5 days for an 8-, 16-, and 24-day delay in sowing compared with the first sowing date (28-Oct). The duration of the filling period of the four sowing dates in the first year was not significantly shortened. In the second year the latest sowing (21-Nov) and earliest sowing (28-Oct) shortened the filling period by 11 days under a delay of 24 days (Table 2).

\section{Morphological traits}

There were differences in the number of tillers at jointing and maturity. The tiller number at the jointing stage of the latest sowing date (21-Nov) was higher than other sowing dates over the two growing seasons. The tiller number of the $21-\mathrm{Nov}$ sowing date was significantly different from that of other sowing dates during the second year. The peak tillers appeared before or after the jointing stage. The peak tillers appeared before the jointing stage for the early sowing date (28Oct) and the normal sowing date (5-Nov), while the late sowing date (13- Nov) and the latest sowing date (21-Nov) occurred after the jointing stage, which was consistent for both years (Table 3). The results of our two-year experiments showed that the tiller number of the 5-Nov sowing date was significantly higher than that of other sowing dates at maturity stage. The percentage of productive tillers on 13-Nov was significantly higher than the other sowing dates. Delayed sowing caused the percentage of productive tillers to increase significantly each 8-day delay in sowing except for the latest sowing date (21-Nov).

\section{Yield formation}


240 The wheat yield varied by both year and sowing date and these factors interacted significantly 241 (Table 4). The grain yield for different sowing dates ranged from 5,569.7 to 6,578.9 $\mathrm{kg} \mathrm{ha}^{-1}$ in 242 2018-2019 and from 5,625.0 to 7,241.7 $\mathrm{kg} \mathrm{ha}^{-1}$ in 2019-2020. Grain yield for each sowing date in $2432019-2020$ was $1.0 \% \sim 10.1 \%$ greater than that in 2018-2019. Grain yield from the 5-Nov sowing date was greater than those of the other treatments during both years. The average grain yield from 5-Nov was $3.2 \%, 18.7 \%$ and $23.4 \%$ greater than the yields of $28-O c t, 13-$ Nov, and 21-Nov, respectively. The results of two-year experiments showed that the yield decreased significantly when the sowing date was delayed for 8 and 16 days after 5-Nov. A consistent declining trend was observed for grain yield after this date until the last sowing date during both years, showing that the longer the delay in sowing date, the greater the yield reduction (Table 4 and Fig. 2). Regression analysis revealed that with each day that grain was sowed early or delayed, the grain yield declined by $0.97 \pm 0.22 \%$ across two years (Fig. 2).

The spike number was affected $(P<0.01)$ by year and sowing date, and the interaction was extremely significant (Table 4$)$. Kernel number per spike reached a very significant level $(P<$ 0.01 ) by year and sowing date, but the interaction term was not significant. 1,000-kernel weight was only affected $(P<0.01)$ by year, and there was no significant difference between the sowing date and these factors. The spike number was positively correlated with wheat grain yield ( $r=$ $0.73, P<0.05)$, whereas the kernel number and 1,000-kernel weight were not. The spike number per ha for 5-Nov was $9.1 \% \sim 30.3 \%$ in 2018-2019 and 8.0\% 19.3\% in 2019-2020, which was greater than that for 28-Oct, 13-Nov and 21-Nov, respectively. The kernel per spike for 21-Nov was $0.5 \%, 8.5 \%$ and $8.2 \%$ in 2018-2019, and $2.7 \%, 8.0 \%$ and $3.7 \%$ in 2019-2020, which was greater than that for 28-Oct, 5-Nov and 13-Nov, respectively.

\section{Dynamics simulation of DMA}

We showed that the dynamic changes of DMA for single stem plants with the days after sowing conforms to the logistic curve model (Fig. 3). The logistic function was followed by DMA as a sigmoidal growth pattern since all $P$ values were $<0.01$ (Table 5), although they differed in equation coefficients among the treatments. The simulated value of DMA for single stem plants was determined using formula (1), and we were able to obtain the characteristic value of dynamic of DMA for single stem plants (Table 6).

We found the beginning and termination day at the rapid accumulation period of winter wheat DMA for single stem under all sowing dates during both years using formulas (2)-(4) based on Table 5. The start of the rapid accumulation period was noted as being after the jointing stage and the termination day was considered to be after the flowering stage. The value of the fastest 
276

277

278

279

280

281

282

283

284

285

286

287

288

289

290

291

292

293

294

295

296

297

298

299

300

301

302

303

304

305

306

307

308

309

310

311

accumulation period over two years was shorter in early sowing $(27.0 \sim 30.6 \mathrm{~d})$ and normal sowing $(19.7 \sim 31.5 \mathrm{~d})$ than in late sowing $(35.9 \sim 37.5 \mathrm{~d})$ and the latest sowing $(36.5 \sim 38.1 \mathrm{~d})$. There were differences among the treatments of DMA for single stem plants under different sowing dates in both years. The maximum relative growth rates $\left(V_{m}\right)$ and highest average rates $\left(V_{t}\right)$ of early sowing and normal sowing were slightly higher than those of late sowing and the latest sowing. The fastest DMA point of single stem growth was during the booting and flowering stages.

Our results showed that $V_{m}$ and $V_{t}$ of early sowing and normal sowing were higher than that of late sowing and the latest sowing. The dynamic accumulation characteristic parameters of DMA for single stem were better and produced better biomass accumulation and yield formation.

\section{Dynamics simulation of NA}

The dynamic changes of NA for single stem plants after sowing were consistent with the changes of DMA. The dynamic changes of NA for single stem conformed to the logistic curve model as the plants grew. It can be seen from Figure 4 that delayed sowing promotes the absorption of $\mathrm{N}$ for single stems of winter wheat, and NA for single stems also increased with the delay of sowing date.

The beginning and termination of the rapid period of accumulation of NA for single stems occurred before the jointing stage and after the booting stage, respectively, according to formulas (2)-(4) based on Table 7. The fastest NA point was from the jointing to the booting stage for different sowing dates in both years. The duration of fast NA for single stem was gradually shortened with the delay of the sowing date. Normal sowing (5-Nov) was postponed by 8 and 16 days, and the average accumulation period was shortened by 0.8 days and 5.2 days. The later the sowing date, the shorter the period of rapid accumulation (Table 8). The maximum relative growth rates $\left(V_{m}\right)$ and highest average rates $\left(V_{t}\right)$ of NA for single stems were different over two years, which showed an increasing trend with the delay of sowing date. The maximum relative growth rates $\left(V_{m}\right)$ and highest average rates $\left(V_{t}\right)$ reached the peak at the latest sowing.

Our results showed that with the delay of sowing date, the coordination of dynamic accumulation characteristic parameters for single stem NA of late sowing wheat was better than that of other treatments. The start of the rapid accumulation period was earlier than that of DMA, indicating that the biomass grew based on adequate nutrient absorption.

\section{Relationships among grain yield, $M_{D} / J_{D}$, and $M_{N} / J_{N}$}


312 Since 5-Nov, the aboveground biomass and N production were significantly reduced with an 313 increase in the number of days that sowing was delayed (Fig. 5). The average DMA decreased by $3148.50 \%$ and $13.32 \%$ after 8 and 16 day delays from normal sowing. The rule of NA remained the same, decreasing by $9.40 \%$ and $12.95 \%$ after 8 and 16 days delayed of normal sowing.

We performed correlation analyses to identify the grain yield associated with the law of DMA and NA. The ratio of DMA at the mature to jointing stages was recorded as $M_{D} / J_{D}$ and the ratio of NA at the mature to jointing stages was recorded as $\mathrm{M}_{\mathrm{N}} / \mathrm{J}_{\mathrm{N}}$. Correlations were observed between the grain yield and $\mathrm{M}_{\mathrm{D}} / \mathrm{J}_{\mathrm{D}}$, and both years showed a very significant positive correlation (Fig. 6a and b). Furthermore, there was a significant positive correlation between yield and $\mathrm{M}_{\mathrm{N}} / \mathrm{J}_{\mathrm{N}}$ (Fig. 6c and d). This suggests that the two ratios have an important influence on the grain yield of winter wheat under different sowing dates.

The linear relationship was found between the grain yield and $\mathrm{M}_{\mathrm{D}} / \mathrm{J}_{\mathrm{D}}(Y=306.03 X+4511.69$ in 2018-2019 and $Y=636.93 X+3924.05$ in 2019-2020) and $\mathrm{M}_{\mathrm{N}} / \mathrm{J}_{\mathrm{N}}(Y=698.98 X+3904.74$ in 20182019 and $Y=1273.29 X+3485.91$ in 2019-2020) (Fig. 6). As $\mathrm{M}_{\mathrm{D}} / \mathrm{J}_{\mathrm{D}}$ and $\mathrm{M}_{\mathrm{N}} / \mathrm{J}_{\mathrm{N}}$ increased, the grain yield increased. The grain yield could be maintained at $6,000 \mathrm{~kg} \mathrm{ha}^{-1}$ or above when the average DMA and NA reached $4.06(P<0.01)$ and $2.49(P<0.05)$, respectively.

\section{Discussion}

\section{Effects of different sowing dates on yield}

We present new data to support the common perception that the sowing date is a crucial agronomic factor for improving, growth, grain yield, and nutrient acquisition of winter wheat. Advancing or delaying beyond the optimum sowing time may hinder the full genetic yield potential of winter wheat. This study evaluated grain yield changes and the biological effects caused by different sowing dates. The grain yield declined by $0.97 \pm 0.22 \%$ with each day that sowing was conducted early or late beyond the normal sowing date (Fig. 2). Previous studies have determined the grain yield declined as a result of delayed sowing with an average yield penalty of approximately $0.37 \pm 0.07 \%$ with each one-day delay in sowing beyond the normal sowing date (Yin et al., 2018; Ma et al., 2018; Dwived et al., 2019; Dubey et al., 2019; Zhu et al., 2019; Gandjaeva, 2019). Those results are comparable with ours. Grain yield reduction as a result of delayed sowing can be explained in terms of suppressed of crop growth, and decreased spike number, dry matter, and $\mathrm{N}$ production.

\section{Changes in weather conditions and crop phenology on different sowing dates}


347 Environmental factors significantly affected the grain yield of wheat that was sown late. It is

348

349

350

351

352

353

354

355

356

357

358

359

360

361

362

363

364

365

366

367

368

369

370

371

372

373

374

375

376

377

378

379

380

381

382 clear that under late sowing conditions, plants faced adverse weather factors such as low temperature and less thermal exposure during sowing to wintering stage compared with the normal sowing date (Fig. 1). For example, the thermal time from the sowing to the wintering period decreased an average of $543.9^{\circ} \mathrm{C} \mathrm{d}$ in normal sowing to $333.8^{\circ} \mathrm{C} \mathrm{d}$ after 16 -days of delayed sowing (Table 1). These disadvantages may affect early crop growth by inhibiting seed emergence, seedling establishment, and tiller development (Shah et al., 2019; Zhou et al., 2020). A delay in sowing will also lead to earlier flowering, reducing the duration of various phases of crop development. The results showed that under the condition of the latest sowing, the crop growth duration from sowing to flowering was shortened by 7.5 days, compared to the normal sowing (Table 2). Shortening of the critical phenological period, as a key factor in determining the photoperiod and productivity of crops, may further explain the poor performance under delayed sowing (Ferrise et al., 2010; Sattar et al., 2010). Delayed sowing also increases the possibility of crops exposure to high temperature during the grain filling stage, which is harmful to leaf photosynthesis, grain filling, and final yield formation. These are considered to be the key stressors for wheat production in many environments around the world (Garg et al., 2013).

\section{Different sowing dates affects tillers}

The environmental limitations posed by late sowing, the inhibition of early growth, and a shorter vegetative growth period led to low tillering ability, poor tiller development, and the reduction of productive tillers. Although late sowing could establish a greater tiller population around the jointing stage, it did not maintain this advantage throughout the growth period. Compared with normal sowing, the tillers decreased significantly at the mature stage, which reduced the percentage of productive tillers (Table 3). The increased seeding rate could make up for the decrease of tillers in the late-sown winter wheat (Wang et al., 2016; Ma et al., 2018). In our study, wheat was planted at a constant density to eliminate the effects of density on wheat growth and grain yield, resulting in the change of spike number with the delay in sowing because of the decreased tillers (Xu et al., 2018; Zhu et al., 2019). However, the reduced plant population could increase the number of fertile stems per plant and the number of kernels per spike, but the magnitude is less than the grain weight (Whaley et al., 2015). This is consistent with our results that the spike number and kernel number were the main factors influencing grain yield. However, there is no correlation between grain yield and 1,000-kernel weight (Table 4).

\section{Different sowing dates affects DMA and NA}

DMA and NA are two primary factors influencing wheat grain yield and grain quality. The demand for high-yielding and high-quality wheat is expected to increase dramatically in the near 
383

384

385

386

387

388

389

390

391

392

393

394

395

396

397

398

399

400

401

402

403

404

405

406

407

408

409

410

411

412

413

414

415

416

417

418

future (Meng et al., 2013; Jin et al., 2018). Reducing the vegetative growth period and tiller number could explain the significant decrease in DMA and final yield under delayed sowing (Shah et al., 2020). The number of tillers decreased significantly with a delay in the sowing date. DMA and NA for single stems played an important role in grain yield and quality. The longest duration of the delayed sowing was longer than that of normal sowing date at the rapid accumulation period of DMA for single stems. This serves to maintain the corresponding accumulation amount although the maximum relative growth rates $\left(V_{m}\right)$ and highest average rates $\left(V_{t}\right)$, which showed that the normal sowing date was slightly higher than the delayed sowing. However, NA for single stems showed the opposite effect. With the delay of sowing date, $V_{m}$ and $V_{t}$ increased gradually, and peaked at the latest sowing. The compensation effect of the rapid accumulation period also showed that the accumulation period was compressed when the sowing date was delayed. There was a relationship between the growth rate of dry matter and the amount of nutrient absorption, but they were not synchronous. The maximum rate of NA occurs earlier than that of DMA (Song et al., 2003). In this study, the accumulation of physiological development time reached maximal accumulation rate $\left(T_{m}\right)$ of DMA for winter wheat 6.4 12.2 days later than that of NA (Table 6 and 8). Therefore, it was necessary to apply N fertilizer at the jointing stage to ensure the nutrient absorption of wheat dry matter and $\mathrm{N}$ during the rapid accumulation period. Our results showed that the final biomass and $\mathrm{N}$ production of the treatment with normal sowing date were significantly higher than those with delayed sowing (Fig. 5), which was consistent with the results of previous studies (Yin et al., 2018; Ferrise et al., 2010).

\section{Directions for future study}

We reiterate the need for sowing at the most suitable time for the maturity length and growing season for a particular variety, which is considered critical for yield optimization. Our results show that sowing in the optimum range can result in a higher yield and that as the sowing date is delayed, the grain yield continues to decline. The highest grain yield was produced with seeds sown on 5-Nov, which occurred due to better weather conditions and a reasonable distribution of thermal time during the wheat growing seasons over two years. The sowing date is an agronomic measure regulated by genotypes and is heavily dependent on the location and environment of crop growth. It is imperative to conduct further multi-location experiments with a diverse set of winter wheat genotypes. A significant aspect would be to compare the yield compensation of different winter wheat genotypes with different tillering capacities and crop growth durations, because these were the most critical traits influenced in response to delayed sowing. Future studies should focus on increasing the seeding rate to compensate for the winter wheat yield reduction caused by delayed sowing. 


\section{Conclusion}

421 Grain yield declined by $0.97 \pm 0.22 \%$ as grains were sown with each one-day early or delay in sowing beyond the normal sowing date. This yield penalty may be due to the inhibition of crop growth, yield components, biomass, and N production. The negative effects of delayed sowing are mainly caused by key environmental limitations including adverse weather factors such as low temperature during vegetative growth, shortened duration of various phases of crop development and increased temperature during grain filling period. In other words, the sowing date determines the weather conditions to which wheat is exposed. However, owing to a compensation effect between the highest average rates $\left(V_{t}\right)$ and the rapid accumulation period $(T)$ of DMA and NA for single stems, the grain yield gap decreased between late and normal sowing. Under these conditions, if the ratio of $\mathrm{M}_{\mathrm{D}} / \mathrm{J}_{\mathrm{D}}$ and $\mathrm{M}_{\mathrm{N}} / \mathrm{J}_{\mathrm{N}}$ could reach $4.06(P<0.01)$ and $2.49(P$ $<0.05$ ) respectively, grain yield could be maintained at the level of $6,000 \mathrm{~kg} \mathrm{ha}^{-1}$ or above. However, delayed sowing caused biomass and $\mathrm{N}$ production to decline. Meanwhile, the accumulation of physiological development time reached maximal accumulation rate $\left(T_{m}\right)$ of NA earlier than that of DMA. We conclude that the reasonable sowing date of winter wheat in the middle-lower Yangtze River Basin around 5-Nov. Further research is needed to explore the compensatory effect of different genotypes of winter wheat on yield under the condition of increasing sowing rate if late sowing is inevitable.

\section{References}

Bailey-Serres J, Parker JE, Ainsworth EA, Oldroyd GED, Schroeder JI. 2019. Genetic strategies for improving crop yields. Nature 575(7781):109-118. DOI 10.1038/s41586-019-1679-0.

Borràsgelonch G, Rebetzke GJ, Richards RA, Romagosa I, Ha C. 2012. Genetic control of duration of pre-anthesis phases in wheat (Triticum aestivum L.) and relationships with leaf apperance, tillering and dry matter accumulation. Journal of Experimental Botany 63(1):69-89. DOI 10.1093/jxb/err230.

Ding DY, Feng H, Zhao Y, He JQ, Zou YF, Jin JM. 2015. Modifying winter wheat sowing date as an adaptation to climate change on the Loess Plateau. Agronomy Journal 108(1):53-63. DOI 10.2134/agronj15.0262.

Du XB, Chen BL, Zhang YX, Zhao WQ, Shen TY, Zhou ZG, Meng YL. 2016. Nitrogen use efficiency of cotton 
451

452

453

454

455

456

457

458

459

460

461

462

463

464

465

466

467

468

469

470

471

472

473

474

475

476

477

478

479

480

481

482

483

484

485

486

487

488

489

490

491

(Gossypium hirsutum L.) as influenced by wheat-cotton cropping systems. European Journal of Agronomy 75:72-79. DOI 10.1016/j.eja.2016.01.001.

Dubey R, Pathak H, Singh S, Chakrabarti B, Fagodiya RK. 2019. Impact of sowing dates on terminal heat tolerance of different wheat (Triticum aestivum L.) cultivars. National Academy Science Letters 42:445-449. DOI 10.1007/s40009-019-0786-7.

Dwivedi SK, Kumar S, Mishra JS, Haris AA, Singh SK, Srivastava AK, Kumar A, Kumar V, Singh S, Bhatt BP. 2019. Effect of moisture regimes and sowing dates on wheat physiological process and yield attributes under rain-fed ecosystem in Eastern Indo Gangetic Plain. Plant Physiology Reports 24:46-53. DOI 10.1007/s40502-018-0406-4.

Ehdaie B, Waines JG. 2001. Sowing date and nitrogen rate effects on dry matter and nitrogen partitioning in bread and durum wheat. Field Crops Research 73:47-61. DOI 10.1016/S0378-4290(01)00181-2.

Fernanda DM, Chapman SC, Rattey AR, Jodi N, Song YH, Christopher JT, Matthew R. 2013. Developmental and growth controls of tillering and water-soluble carbohydrate accumulation in contrasting wheat (Triticum aestivum L.) genotypes: can we dissect them? Journal of Experimental Botany 64(1):143-160. DOI $10.1093 / \mathrm{jxb} / \mathrm{ers} 317$.

Ferrise R, Triossi A, Stratonovitch P, Bindi M, Martre P. 2010. Sowing date and nitrogen fertilisation effects on dry matter and nitrogen dynamics for durum wheat: An experimental and simulation study. Field Crops Research 117:245-257. DOI 10.1016/j.fcr.2010.03.010.

Gandjaeva L. 2019. Effect of sowing date on yield of winter wheat cultivars Grom, Asr and Kuma in Khorezm region. Bulgarian Journal of Agricultural Science 25(3):474-479.

Garg D, Sareen S, Dalal S, Tiwari R, Singh R. 2013. Grain filling duration and temperature pattern influence on the performance of wheat genotypes under late planting. Cereal Research Communications 41(3):500-507. DOI 10.1556/CRC.2013.0019.

Geng X, Wang F, Ren W, Hao ZX. 2019. Climate change impacts on winter wheat yield in northern China. Advances in Meteorology 2019:1-12. DOI 10.1155/2019/2767018.

Gupta RK, Naresh RK, Hobbs PR, Zheng JG, Ladha JK. 2003. Sustainability of Post-Green Revolution Agriculture: The rice-wheat cropping systems of the Indo-Gangetic Plains and China. Improving the Productivity and Sustainability of Rice-wheat Systems: Issues and Impacts An International Symposium 65:1-25. DOI 10.2134/asaspecpub65.c1.

He L, Asseng S, Zhao G, Wu DR, Yang XY, Zhuang W, Jin N, Yu Q. 2015. Impacts of recent climate warming, cultivar changes, and crop management on winter wheat phenology across the Loess Plateau of China. Agricultural and Forest Meteorology 200:135-143. DOI 10.1016/j.agrformet.2014.09.011.

He L, Cleverly J, Chen C, Yang X, Yu Q. 2014. Diverse responses of winter wheat yield and water use to climate change and variability on the Semiarid Loess Plateau in China. Agronomy Journal 106(4):1169-1178. DOI 10.2134/agronjx13.0321.

Hussain S, Khaliq A, Bajwa AA, Matloob A, Areeb A, Ashraf U, Hafeez A, Imran M. 2017. Crop growth and yield losses in wheat due to little seed canary grass infestation differ with weed densities and changes in environment. Planta Daninha 35:1-15. DOI 10.1590/s0100-83582017350100073.

Jackson LF, Dubcovsky J, Gallagher LW, Wenning RL, Wright S. 2000. Regional barley and common and durum wheat performance tests in California. Agronmy Progress Report 272:1-56.

Jain RC, Agrawal R, Singh KN. 2010. A within year growth model for crop yield forecasting. Biometrical Journal, 
492

493

494

495

496

497

498

499

500

501

502

503

504

505

506

507

508

509

510

511

512

513

514

515

516

517

518

519

520

521

522

523

524

525

526

527

528

529

530

531

532

34(7):789-799. DOI 10.1002/bimj.4710340705.

Jalota SK, Kaur H, Kaur S, Vashisht BB. 2013. Impact of climate change scenarios on yield, water and nitrogenbalance and use efficiency of rice-wheat cropping system. Agricultural Water Management 116:29-38. DOI 10.1016/j.agwat.2012.10.010.

Jin XF, Feng B, Xu ZB, Fan XL, Liu J, Liu Q, Zhu P, Wang T. 2018. TaAAP6-3B, a regulator of grain protein content selected during wheat improvement. Bmc Plant Biology 18(1):71. DOI 10.1186/s12870-018-1280-y.

Karimizadeh R, Mohammadi M. 2011. Association of canopy temperature depression with yield of durum wheat genotypes under supplementary irrigated and rainfed conditions. Australian Journal of Crop Science 5(2):138-146. DOI 10.1016/j.jbspin.2006.08.001.

Kaur C. 2017. Performance of wheat varieties under late and very late sowing conditions. International Journal of Current Microbiology and Applied Sciences 6(9):3488-3492. DOI 10.20546/ijcmas.2017.609.428.

Liu X, Xu SS, Zhang JW, Ding YF, Li GH, Wang SH, Liu ZH, Tang S, Ding CQ, Chen L. 2016. Effect of continuous reduction of nitrogen application to a rice-wheat rotation system in the middle-lower Yangtze River region (2013-2015). Field Crops Research 196:348-356. DOI 10.1016/j.fcr.2016.07.003.

$\mathrm{Lu}$ CH, Fan L. 2013. Winter wheat yield potentials and yield gaps in the North China Plain. Field Crops Research 143:98-105. DOI 10.1016/j.fcr.2012.09.015.

Ma SC, Wang TC, Guan XK, Zhang X. 2018. Effect of sowing time and seeding rate on yield components and water use efficiency of winter wheat by regulating the growth redundancy and physiological traits of root and shoot. Field Crops Research 221:166-174. DOI 10.1016/j.fcr.2018.02.028.

Meng QF, Yue SC, Chen XP, Cui ZL, Ye YL, Ma WQ, Tong YN, Zhang FS. 2013. Understanding dry matter and nitrogen accumulation with time-course for high-yielding wheat production in China. Plos One 8(7):e68783. DOI 10.1371/journal.pone.0068783.

Royo C, Blanco R. 1999. Growth analysis of five spring and five winter triticale genotypes. Agronomy Journal 91(2):305-311. DOI 10.2134/agronj1999.00021962009100020020x.

Sattar A, Cheema MA, Farooq M, Wahid MA, Wahid A, Babar BH. 2010. Evaluating the performance of wheat cultivars under late sown conditions. International Journal of Agriculture and Biology 12(4):1560-853012. DOI 10.1016/j.compag.2010.03.005.

Shah F, Coulter JA, Ye C, Wu W. 2020. Yield penalty due to delayed sowing of winter wheat and the mitigatory role of increased seeding rate. European Journal of Agronomy 119:126120. DOI 10.1016/j.eja.2020.126120.

Shah T, Latif S, Khan H, Munsif F, Nie L. 2019. Ascorbic acid priming enhances seed germination and seedling growth of winter wheat under low temperature due to late sowing in Pakistan. Agronomy 9(11):757. DOI 10.3390/agronomy9110757.

Song HX, Li SX. 2003. Dynamics of nutrient accumulation in maize plants under different water and N supply conditions. Scientia Agricultura Sinica 36(1):71-76. DOI CNKI:SUN:ZNYK.0.2003-01-012.

Sun HL, Geng SY, Wang XY, Xiong QX. 2019. Estimation method of wheat leaf area index based on hyperspectral under late sowing conditions. Spectroscopy and Spectral Analysis 39(04):1199-1206. DOI CNKI:SUN:GUAN.0.2019-04-037.

Sun Z, Jia SF, Lv AF, Yang KJ, Gao YC. 2015. Impacts of climate change on growth period and planting boundaries of winter wheat in China under RCP4.5 scenario. Earth System Dynamics Discussions 6(2):2181-2210. DOI 10.5194/esdd-6-2181-2015. 
533

534

535

536

537

538

539

540

541

542

543

544

545

546

547

548

549

550

551

552

553

554

555

556

557

558

559

560

561

562

563

564

565

566

567

568

569

570

571

572

573

Tester M, Langridge P. 2010. Breeding technologies to increase crop production in a changing world. Science 327(5967):818-822. DOI 10.1126/science.1183700.

Wang B, Zhang YH, Hao BZ, Xu XX, Zhao ZG, Wang ZM, Xue QW. 2016. Grain yield and water use efficiency in extremely-late sown winter wheat cultivars under two irrigation regimes in the North China Plain. Plos One 11(4):e0153695. DOI 10.1371/journal.pone.0153695.

Wang XX, Wang QJ, Fan J, Sun LJ, Shen XL. 2014. Logistic model analysis of winter wheat growth on China's Loess Plateau. Canadian Journal of Plantence 94(8):1471-1479. DOI 10.4141/cjps2013-293.

Whaley JM, Sparkes DL, Foulkes MJ, Spink JH, Scott RK. 2015. The physiological response of winter wheat to reductions in plant density. Annals of Applied Biology 137(2):165-177. DOI 10.1111/j.17447348.2000.tb00048.x.

Whisler FD, Acock B, Baker DN, Fye RE, Hodges HF, Lambert JR, Lemmon HE, Mckinion JM, Reddy VR. 1986. Crop simulation models in agronomic systems. Advances in Agronomy 40:141-208. DOI 10.1016/S00652113(08)60282-5.

Wu LWT. 2020. Food and Agricultural Organization of the United Nations. Journal of Association of Official Agricultural Chemists 45(2):508-509.

Wu W, Li CJ, Ma BL, Shah F, Liu Y, Liao YC. 2014. Genetic progress in wheat yield and associated traits in China since 1945 and future prospects. Euphytica 196(2):155-168. DOI 10.1007/s10681-013-1033-9.

Xiao DP, Moiwo JP, Tao FL, Yang YH, Shen YJ, Xu QH, Liu JF, Zhang H, Liu FS. 2015. Spatiotemporal variability of winter wheat phenology in response to weather and climate variability in China. Mitigation and Adaptation Strategies for Global Change 20(7):1191-1202. DOI 10.1007/s11027-013-9531-6.

Xiao DP, Tao FL, Liu YJ, Shi WJ, Wang M, Liu FS, Zhang S, Zhu Z. 2013. Observed changes in winter wheat phenology in the North China Plain for 1981-2009. International Journal of Biometeorology 57(2):275285. DOI 10.1007/s00484-012-0552-8.

Xiao Q, Yan LB, Zhu XY, Zhang HW, Cao B, Ni XH, Li LX, Yang JG, Huang DM, Yi WP. 2014. Dynamic analysis of dry matter and NPK accumulation with time in summer maize. Journal of Plant Nutrition and Fertilizer 20(3):606-612. DOI CNKI:SUN:ZWYF.0.2014-03-011.

Xu CL, Zhao HX, Zhang P, Wang YY, Huang SB, Meng QF, Wang P. 2018. Delaying wheat seeding time and maize harvest improved water use efficiency in a warm temperature continental monsoon climate. Agronomy Journal 110(4):1420-1429. DOI 10.2134/agronj2017.10.0613.

Xu K, Sun Z, Huo ZY, Dai QG, Zhang HC, Liu J, Song YS, Yang DL, Wei HY, Wu AG. 2013. Effects of seeding date and variety type on yield, growth stage and utilization of temperature and sunshine in rice. Scientia Agricultura Sinica 46(20):4222-4233. DOI 10.3864/j.issn.0578-1752.2013.20.005.

Yin LJ, Dai XL, He MR. 2018. Delayed sowing improves nitrogen utilization efficiency in winter wheat without impacting yield. Field Crops Research 221:90-97. DOI 10.1016/j.fcr.2018.02.015.

Yin LJ, Xu HC, Dong SX, Chu JP, Dai XL, He MR. 2019. Optimised nitrogen allocation favours improvement in canopy photosynthetic nitrogen-use efficiency: Evidence from late-sown winter wheat. Environmental and Experimental Botany 159:75-86. DOI 10.1016/j.envexpbot.2018.12.013.

Zadoks JC. 2010. A decimal code for the growth stages of cereals. Weed Research 14(6):415-421. DOI 10.1111/j.1365-3180.1974.tb01084.x.

Zhang JH, Liu JL, Zhang JB, Cheng YN, Wang WP. 2013. Nitrate-nitrogen dynamics and nitrogen budgets in ricewheat rotations in Taihu Lake Region, China. Pedosphere 23(1):59-69. DOI 10.1016/S1002-

Peer] reviewing PDF | (2021:01:57230:1:2:NEW 19 May 2021) 
$574 \quad 0160(12) 60080-0$.

575 Zhao J, Zheng ZF, Fang YR, Zhou SL, Wang P. 2013. Effect of dry matter accumulation characteristics on yield of 576 winter wheat analyzed by dynamic simulation model. Acta Agronomica Sinica 39(2):300-308. DOI

$577 \quad 10.3724 /$ SP.J.1006.2013.00300.

578 Zheng YF, Xu JX, Wu RJ. 2013. Effects of different shading condition on dry matter accumulation and distribution 579 of winter wheat. Chinese Journal of Agrometeorology 34(1):64-73. DOI 10.3969/j.issn.1000-

$580 \quad 6362.2013 .01 .010$.

581 Zhou BY, Su XF, Ge JZ, Li CF. 2020. Wheat growth and grain yield responses to sowing date-associated variations in weather conditions. Agronomy Journal 112(2):985-997. DOI 10.1002/agj2.20122.

Zhu YG, Chu JP, Dai XL, He MR. 2019. Delayed sowing increases grain number by enhancing spike competition capacity for assimilates in winter wheat. European Journal of Agronomy 104:49-62. DOI 10.1016/j.eja.2019.01.006.

586

587

588

589

590

591

592

593 Additional Information and Declarations

\section{Competing Interests}

595 The authors declare that they have no competing interests.

\section{Author Contributions}

597 Kaizhen Liu conceived and designed the experiments, performed the experiments, analyzed the 598 data, contributed reagents/materials/analysis tools, prepared figures and/or tables, authored or 599 reviewed drafts of the paper, and approved the final draft. 
600 Chengxiang Zhang performed the experiments, and approved the final draft.

601 BeiBei Guan performed the experiments, and approved the final draft.

602 Rui Yang performed the experiments, and approved the final draft.

603 Ke Liu performed the experiments, and approved the final draft.

604 Zhuangzhi Wang performed the experiments, and approved the final draft.

605 Xiu Li performed the experiments, and approved the final draft.

606 Keyin Xue performed the experiments, and approved the final draft.

607 Lijun Yin performed the experiments, analyzed the data, contributed reagents/materials/analysis 608 tools, prepared figures and/or tables, and approved the final draft.

609 Xiaoyan Wang conceived and designed the experiments, analyzed the data, contributed 610 reagents/materials/analysis tools, prepared figures and/or tables, authored or reviewed drafts of 611 the paper, and approved the final draft.

\section{Acknowledgement}

613 This research was supported by the National Natural Science Foundation of China (31871578)

614 and the National Key Research and Development Program of China (2016YFD0300107, 615 2017YFD0300205). There was no additional external funding received for this study. The 616 funders had no role in study design, data collection and analysis, decision to publish, or 617 preparation of the manuscript.

\section{Figures}

Figure 1 Average temperature and precipitation over two growing seasons.

Figure 2 Grain yield loss of winter wheat due to the early and delayed sowing during 20182019 and 2019-2020 growing seasons.

624

Figure 3 Effects of different sowing dates on DMA for single stem in 2018-2019 and 2019- 
627

628 Figure 4 Effects of different sowing dates on NA dynamics for single stem in 2018-2019 and 629 2019-2020.

630

631

632

633

634

635

636

637

638

639

640

641

642

643

644

645

646

647

648

649

650

651

652

653

654

655

656

657

658

Figure 5 Biomass production and $\mathrm{N}$ production of winter wheat under different sowing date during 2018-2019 and 2019-2020 growing seasons.

Figure 6 Relationships between grain yield and four ratios.

\section{Tables}

Table 1 The soil fertility status of the tested soil $(0-20 \mathrm{~cm})$.

Table 2 Statistics of growth time and meteorological data of different sowing dates in growing season of 2018-2019 and 2019-2020.

Table 3 The number of tillers and effective tiller rate of winter wheat at different sowing dates in 2018-2019 and 2019-2020 growing seasons.

Table 4 Grain yield and yield components for different sowing dates in 2018-2019 and 2019-2020 growing seasons.

Table 5 Equations of DMA under different sowing dates in 2018-2019 and 2019-2020 growing seasons.

Table 6 Effects of different sowing dates on the eigenvalues of DMA in 2018-2019 and 20192020 growing seasons.

Table 7 Equations of NA under different sowing dates in 2018-2019 and 2019-2020 growing seasons.

Table 8 Effects of different sowing dates on the eigenvalues of NA in 2018-2019 and 20192020 growing seasons. 


\section{Table $\mathbf{1}$ (on next page)}

Table 1 The soil fertility status of the tested soil $(0-20 \mathrm{~cm})$. 


\section{$1 \quad$ Table 1}

2 Table 1 The soil fertility status of the tested soil $(0-20 \mathrm{~cm})$.

\begin{tabular}{cccccc}
\hline Season & $\mathrm{pH}$ & $\begin{array}{c}\text { Organic } \\
\text { matter } \\
\left(\mathrm{g} \cdot \mathrm{kg}^{-1}\right)\end{array}$ & $\begin{array}{c}\text { Alkali hydrolyzed nitrogen } \\
\left(\mathrm{mg} \cdot \mathrm{kg}^{-1}\right)\end{array}$ & $\begin{array}{c}\text { Available } \\
\text { phosphorous } \\
\left(\mathrm{mg} \cdot \mathrm{kg}^{-1}\right)\end{array}$ & $\begin{array}{c}\text { Available } \\
\text { potassium } \\
\left(\mathrm{mg} \cdot \mathrm{kg}^{-1}\right)\end{array}$ \\
\hline $2018-2019$ & 8.23 & 17.9 & 60.5 & 21.9 & 116.6 \\
$2019-2020$ & 8.19 & 14.8 & 42.8 & 7.3 & 75.7 \\
\hline
\end{tabular}

3 


\section{Table 2 (on next page)}

Table 2 Statistics of growth time and meteorological data of different sowing dates in growing season of 2018-2019 and 2019-2020. 


\section{Table 2}

2 Table 2 Statistics of growth time and meteorological data of different sowing dates in growing 3 season of 2018-2019 and 2019-2020.

\begin{tabular}{|c|c|c|c|c|c|c|}
\hline Season & $\begin{array}{c}\text { Sowing } \\
\text { date }\end{array}$ & $\begin{array}{l}\text { Days for sowing } \\
\text { to flowering } \\
\text { stage (d) }\end{array}$ & $\begin{array}{l}\text { Days for } \\
\text { filling stage } \\
\text { (d) }\end{array}$ & $\begin{array}{c}\text { Accumulated } \\
\text { temperature during the } \\
\text { whole growth period } \\
\left({ }^{\circ} \mathrm{C}\right)\end{array}$ & $\begin{array}{l}\text { Thermal time } \\
\text { from sowing to } \\
\text { wintering stage } \\
\qquad\left({ }^{\circ} \mathrm{C} \mathrm{d}\right)\end{array}$ & $\begin{array}{l}\text { Mean daily } \\
\text { temperature during } \\
\text { filling stage }\left({ }^{\circ} \mathrm{C}\right)\end{array}$ \\
\hline \multirow[t]{4}{*}{$2018-2019$} & $28-O c t$ & 164 & 38 & 2141.2 & 623.0 & 20.08 \\
\hline & 5-Nov & 159 & 37 & 2048.6 & 486.2 & 20.28 \\
\hline & $13-\mathrm{Nov}$ & 153 & 36 & 1978.9 & 397.6 & 20.48 \\
\hline & 21-Nov & 149 & 36 & 1985.2 & 310.2 & 20.71 \\
\hline \multirow[t]{4}{*}{$2019-2020$} & 28 -Oct & 146 & 50 & 2304.6 & 741.6 & 17.93 \\
\hline & $5-\mathrm{Nov}$ & 143 & 46 & 2187.1 & 601.6 & 18.23 \\
\hline & $13-\mathrm{Nov}$ & 142 & 43 & 2140.7 & 469.3 & 19.84 \\
\hline & 21-Nov & 138 & 39 & 2028.8 & 357.4 & 20.25 \\
\hline
\end{tabular}

4 


\section{Table 3 (on next page)}

Table 3 The number of tillers and effective tiller rate of winter wheat at different sowing dates in 2018-2019 and 2019-2020 growing seasons.

Values followed by the same letter within a column in the same year are not significantly different at $P<0.05$ as determined by the LSD test. 


\section{$1 \quad$ Table 3}

2 Table 3 The number of tillers and effective tiller rate of winter wheat at different sowing dates in 3 2018-2019 and 2019-2020 growing seasons.

\begin{tabular}{|c|c|c|c|c|c|}
\hline Season & $\begin{array}{l}\text { Sowing } \\
\text { date }\end{array}$ & $\begin{array}{l}\text { Tiller number at jointing } \\
\text { stage (no. } \mathrm{m}^{-2} \text { ) }\end{array}$ & $\begin{array}{l}\text { Tiller number at maturity } \\
\text { stage (no. } \mathrm{m}^{-2} \text { ) }\end{array}$ & $\begin{array}{l}\text { Peak tillers (no. } \\
\qquad \mathrm{m}^{-2} \text { ) }\end{array}$ & $\begin{array}{c}\text { Percentage of productive } \\
\text { tillers }(\%)\end{array}$ \\
\hline $\begin{array}{l}2018- \\
2019\end{array}$ & 28 -Oct & $530.67 b$ & $444.00 \mathrm{~b}$ & $785.33 \mathrm{a}$ & $56.65 \mathrm{c}$ \\
\hline \multirow{7}{*}{$\begin{array}{l}2019- \\
2020\end{array}$} & $5-\mathrm{Nov}$ & $636.00 \mathrm{a}$ & $484.33 \mathrm{a}$ & $754.67 \mathrm{a}$ & $64.23 b$ \\
\hline & 13-Nov & $596.00 \mathrm{ab}$ & $437.67 b$ & $596.00 \mathrm{~b}$ & $73.45 a$ \\
\hline & 21-Nov & $640.00 \mathrm{a}$ & $371.67 \mathrm{c}$ & $640.00 \mathrm{~b}$ & $58.33 \mathrm{bc}$ \\
\hline & 28 -Oct & $524.00 \mathrm{c}$ & $432.00 \mathrm{~b}$ & $1078.67 \mathrm{a}$ & $40.06 \mathrm{c}$ \\
\hline & 5-Nov & $642.33 b$ & $466.67 \mathrm{a}$ & $876.00 \mathrm{~b}$ & $53.48 \mathrm{~b}$ \\
\hline & 13-Nov & $660.00 \mathrm{~b}$ & $411.67 \mathrm{c}$ & $660.00 \mathrm{c}$ & $62.38 \mathrm{a}$ \\
\hline & 21-Nov & $701.33 \mathrm{a}$ & $391.33 d$ & $701.33 \mathrm{c}$ & $55.80 \mathrm{~b}$ \\
\hline
\end{tabular}

4 Values followed by the same letter within a column in the same year are not significantly different at $P<0.05$ as determined by the LSD 5 test. 


\section{Table 4 (on next page)}

Table 4 Grain yield and yield components for different sowing dates in 2018-2019 and 2019-2020 growing seasons.

Values followed by the same letter within a column in the same year are not significantly different at $P<0.05$ as determined by the LSD test. 


\section{Table 4}

2 Table 4 Grain yield and yield components for different sowing dates in 2018-2019 and 201932020 growing seasons.

\begin{tabular}{|c|c|c|c|c|c|}
\hline Season & Sowing date & $\begin{array}{l}\text { Grain yield } \\
\left(\mathrm{kg} \mathrm{ha}^{-1}\right)\end{array}$ & $\begin{array}{l}\text { Spike number } \\
\qquad\left(10^{4} \mathrm{ha}^{-1}\right)\end{array}$ & $\begin{array}{l}\text { Kernel number per } \\
\text { spike }\end{array}$ & $\begin{array}{l}\text { 1000-kernel weight } \\
\text { (g) }\end{array}$ \\
\hline \multirow[t]{4}{*}{ 2018-2019 } & $28-\mathrm{Oct}$ & $6403.8 \mathrm{a}$ & $444.0 \mathrm{~b}$ & $40.8 \mathrm{a}$ & $40.5 \mathrm{a}$ \\
\hline & $5-\mathrm{Nov}$ & $6578.9 \mathrm{a}$ & $484.3 \mathrm{a}$ & $37.8 \mathrm{~b}$ & $40.6 \mathrm{a}$ \\
\hline & 13-Nov & $5674.8 \mathrm{~b}$ & $437.7 \mathrm{~b}$ & $37.9 \mathrm{~b}$ & $40.9 \mathrm{a}$ \\
\hline & 21-Nov & $5569.7 \mathrm{~b}$ & $371.7 \mathrm{c}$ & $41.0 \mathrm{a}$ & $41.1 \mathrm{a}$ \\
\hline \multirow[t]{4}{*}{ 2019-2020 } & 28-Oct & $6980.0 \mathrm{~b}$ & $432.0 \mathrm{~b}$ & $40.9 \mathrm{~b}$ & $46.9 \mathrm{a}$ \\
\hline & 5-Nov & $7241.7 \mathrm{a}$ & $466.7 \mathrm{a}$ & $38.9 \mathrm{c}$ & $47.2 \mathrm{a}$ \\
\hline & 13-Nov & $5958.3 \mathrm{c}$ & $411.7 \mathrm{c}$ & $40.5 b$ & $47.7 \mathrm{a}$ \\
\hline & 21-Nov & $5625.0 \mathrm{~d}$ & $391.3 \mathrm{~d}$ & $42.0 \mathrm{a}$ & $48.1 \mathrm{a}$ \\
\hline \multicolumn{2}{|c|}{ Year } & .0001 & .0002 & .0010 & .0001 \\
\hline \multicolumn{2}{|c|}{ SD } & .0001 & .0001 & .0001 & .1425 \\
\hline \multicolumn{2}{|c|}{$\mathrm{Y} \times \mathrm{SD}$} & .0003 & .0001 & .0627 & .8184 \\
\hline
\end{tabular}

4 Values followed by the same letter within a column in the same year are not significantly different at $P<0.05$ as determined by the LSD 5 test. 


\section{Table 5 (on next page)}

Table 5 Equations of DMA under different sowing dates in 2018-2019 and 2019-2020 growing seasons.

${ }^{* *}$ Significant differences at $P<0.01$ probability levels $(n=6)$. 


\section{Table 5}

2 Table 5 Equations of DMA under different sowing dates in 2018-2019 and 2019-2020 growing 3 seasons.

\begin{tabular}{|c|c|c|c|}
\hline Season & Sowing date & Regression equations & $R^{2}$ \\
\hline \multirow[t]{4}{*}{ 2018-2019 } & 28-Oct & $Y=3.6217 /\left(1+4101240.31 \mathrm{e}^{-0.0976 t}\right)$ & $0.9941^{* *}$ \\
\hline & $5-\mathrm{Nov}$ & $Y=3.0897 /\left(1+420518907.20 \mathrm{e}^{-0.1339 t}\right)$ & $0.9909^{* *}$ \\
\hline & 13-Nov & $Y=3.5946 /\left(1+45779.88 \mathrm{e}^{-0.0701 t}\right)$ & $0.9992^{* *}$ \\
\hline & 21-Nov & $Y=3.9149 /\left(1+48761.68 \mathrm{e}^{-0.0722 t}\right)$ & $0.9995^{* *}$ \\
\hline \multirow[t]{4}{*}{ 2019-2020 } & 28-Oct & $Y=3.1812 /\left(1+109524.11 \mathrm{e}^{-0.0862 t}\right)$ & $0.9925^{* *}$ \\
\hline & $5-\mathrm{Nov}$ & $Y=3.1866 /\left(1+91308.58 \mathrm{e}^{-0.0836 t}\right)$ & $0.9949^{* *}$ \\
\hline & 13-Nov & $Y=3.0814 /\left(1+20681.61 \mathrm{e}^{-0.0734 t}\right)$ & $0.9977^{* *}$ \\
\hline & 21-Nov & $Y=3.2251 /\left(1+10799.99 \mathrm{e}^{-0.0692 t}\right)$ & $0.9981^{* *}$ \\
\hline
\end{tabular}

${ }^{* *}$ Significant differences at $P<0.01$ probability levels $(\mathrm{n}=6)$. 


\section{Table 6(on next page)}

Table 6 Effects of different sowing dates on the eigenvalues of DMA in 2018-2019 and 2019-2020 growing seasons.

$T_{1}$ and $T_{2}$ : Beginning and termination days of the duration of fast accumulation phase; $T=T_{2^{-}}$ $T_{1}$ : Duration of the physiological development time in rapid accumulation period; $V_{t}$ : Average accumulation rate during the duration of fast accumulation phase; $T_{m}$ : Accumulation of physiological development time reached maximal accumulation rate; $V_{m}$ : Maximum accumulation rate during the duration of fast accumulation phase, respectively. 


\section{Table 6}

2 Table 6 Effects of different sowing dates on the eigenvalues of DMA in 2018-2019 and 201932020 growing seasons.

\begin{tabular}{cccccccc}
\hline \multirow{2}{*}{ Season } & Sowing date & \multicolumn{3}{c}{ Fast accumulation period } & \multicolumn{2}{c}{ Fastest accumulation point } \\
\cline { 3 - 8 } & & $T_{1}(\mathrm{~d})$ & $T_{2}(\mathrm{~d})$ & $T(\mathrm{~d})$ & $V_{\mathrm{t}}\left(\mathrm{g} \mathrm{stem}^{-1} \mathrm{~d}^{-1}\right)$ & $T_{\mathrm{m}}(\mathrm{d})$ & $V_{\mathrm{m}}\left(\mathrm{g} \mathrm{stem}^{-1} \mathrm{~d}^{-1}\right)$ \\
\hline \multirow{2}{*}{$2018-2019$} & 28 -Oct & 142.5 & 169.5 & 27.0 & 0.08 & 156.0 & 0.09 \\
& 5-Nov & 138.5 & 158.2 & 19.7 & 0.09 & 148.4 & 0.10 \\
& 13-Nov & 134.2 & 171.8 & 37.5 & 0.06 & 153.0 & 0.06 \\
& 21-Nov & 131.4 & 167.9 & 36.5 & 0.06 & 149.6 & 0.07 \\
& 28-Oct & 119.4 & 150.0 & 30.6 & 0.06 & 134.7 & 0.07 \\
& 5-Nov & 120.9 & 152.4 & 31.5 & 0.06 & 136.6 & 0.07 \\
& 13-Nov & 117.4 & 153.3 & 35.9 & 0.05 & 135.4 & 0.06 \\
& 21-Nov & 115.3 & 153.3 & 38.1 & 0.05 & 134.3 & 0.06 \\
\hline
\end{tabular}

$4 T_{1}$ and $T_{2}$ : Beginning and termination days of the duration of fast accumulation phase; $T=T_{2^{-}} T_{1}$ : Duration of the physiological

5 development time in rapid accumulation period; $V_{t}$ : Average accumulation rate during the duration of fast accumulation phase; $T_{m}$ :

6 Accumulation of physiological development time reached maximal accumulation rate; $V_{m}$ : Maximum accumulation rate during the

7 duration of fast accumulation phase, respectively. 


\section{Table 7 (on next page)}

Table 7 Equations of NA under different sowing dates in 2018-2019 and 2019-2020 growing seasons.

${ }^{*}$ Significant differences at $P<0.01$ probability levels $(n=6)$. 


\section{Table 7}

2 Table 7 Equations of NA under different sowing dates in 2018-2019 and 2019-2020 growing 3 seasons.

\begin{tabular}{cccc}
\hline Season & Sowing date & Regression equations & $R^{2}$ \\
\hline $2018-2019$ & 28 -Oct & $Y=44.2207 /\left(1+436306.39 \mathrm{e}^{-0.0906 t}\right)$ & $0.9808^{* *}$ \\
& 5-Nov & $Y=44.6148\left(1+839280.29 \mathrm{e}^{-0.0960 \mathrm{t}}\right)$ & $0.9874^{* *}$ \\
& 13-Nov & $Y=46.4937 /\left(1+1030959.01 \mathrm{e}^{-0.0986 \mathrm{t}}\right)$ & $0.9932^{*}$ \\
21 -Nov & $Y=50.2932 /\left(1+3464573.17 \mathrm{e}^{-0.1109 t}\right)$ & $0.9980^{*}$ \\
$2019-2020$ & 28-Oct & $Y=44.8498 /\left(1+28575.36 \mathrm{e}^{-0.0834 t}\right)$ & $0.9787^{* *}$ \\
& 5-Nov & $Y=51.9671 /\left(1+12335.05 \mathrm{e}^{-0.0724 t}\right)$ & $0.9782^{* *}$ \\
& 13-Nov & $Y=52.0154 /\left(1+12551.56 \mathrm{e}^{-0.0741 t}\right)$ & $0.9838^{* *}$ \\
& 21-Nov & $Y=54.2685 /\left(1+62975.43 \mathrm{e}^{-0.0888 t}\right)$ & $0.9872^{* *}$ \\
\hline
\end{tabular}

${ }^{* *}$ Significant differences at $P<0.01$ probability levels $(\mathrm{n}=6)$. 


\section{Table 8(on next page)}

Table 8 Effects of different sowing dates on the eigenvalues of NA in 2018-2019 and 2019-2020 growing seasons.

$T_{1}$ and $T_{2}$ : Beginning and termination days of the duration of fast accumulation phase; $T=T_{2^{-}}$ $T_{1}$ : Duration of the physiological development time in rapid accumulation period; $V_{t}$ : Average accumulation rate during the duration of fast accumulation phase; $T_{m}$ : Accumulation of physiological development time reached maximal accumulation rate; $V_{m}$ : Maximum accumulation rate during the duration of fast accumulation phase, respectively. 


\section{$1 \quad$ Table 8}

2 Table 8 Effects of different sowing dates on the eigenvalues of NA in 2018-2019 and 2019-2020

3 growing seasons.

\begin{tabular}{cccccccc}
\hline \multirow{2}{*}{ Season } & Sowing date & \multicolumn{3}{c}{ Fast accumulation period } & \multicolumn{2}{c}{ Fastest accumulation point } \\
\cline { 3 - 7 } & & $T_{1}(\mathrm{~d})$ & $T_{2}(\mathrm{~d})$ & $T(\mathrm{~d})$ & $V_{\mathrm{t}}\left(\mathrm{g} \mathrm{stem}^{-1} \mathrm{~d}^{-1}\right)$ & $T_{\mathrm{m}}(\mathrm{d})$ & $V_{\mathrm{m}}\left(\mathrm{g} \mathrm{stem}^{-1} \mathrm{~d}^{-1}\right)$ \\
\hline \multirow{2}{*}{$2018-2019$} & $28-\mathrm{Oct}$ & 128.8 & 157.9 & 29.1 & 0.88 & 143.3 & 1.00 \\
& 5-Nov & 128.4 & 155.8 & 27.4 & 0.94 & 142.1 & 1.07 \\
& 13-Nov & 127.0 & 153.7 & 26.7 & 1.01 & 140.4 & 1.15 \\
& 21-Nov & 123.9 & 147.7 & 23.8 & 1.22 & 135.8 & 1.39 \\
& 28-Oct & 107.3 & 138.8 & 31.6 & 0.82 & 123.1 & 0.93 \\
& 5-Nov & 111.9 & 148.3 & 36.4 & 0.82 & 130.1 & 0.94 \\
& 13-Nov & 109.6 & 145.1 & 35.5 & 0.85 & 127.3 & 0.96 \\
& 21-Nov & 109.6 & 139.3 & 29.7 & 1.06 & 124.5 & 1.20 \\
\hline
\end{tabular}

$4 T_{1}$ and $T_{2}$ : Beginning and termination days of the duration of fast accumulation phase; $T=T_{2^{-}} T_{1}$ : Duration of the physiological

5 development time in rapid accumulation period; $V_{t}$ : Average accumulation rate during the duration of fast accumulation phase; $T_{m}$ :

6 Accumulation of physiological development time reached maximal accumulation rate; $V_{m}$ : Maximum accumulation rate during the

7 duration of fast accumulation phase, respectively.

8 


\section{Figure 1}

Figure 1 Average temperature and precipitation over two growing seasons.

Top panel shows data from the 2018-2019 growing season, while the bottom panel shows data from the 2019-2020 growing season. Black lines indicate average temperatures in 2018.10-2019.5 and 2019.10-2020.5, respectively. Black bars indicate precipitation events during 2018.10-2019.5 and 2019.10-2020.5, respectively. Date was collected by the local meteorological bureau of Jingzhou. 


\section{Figure 1}

Figure 1 Average temperature and precipitation over two growing seasons.
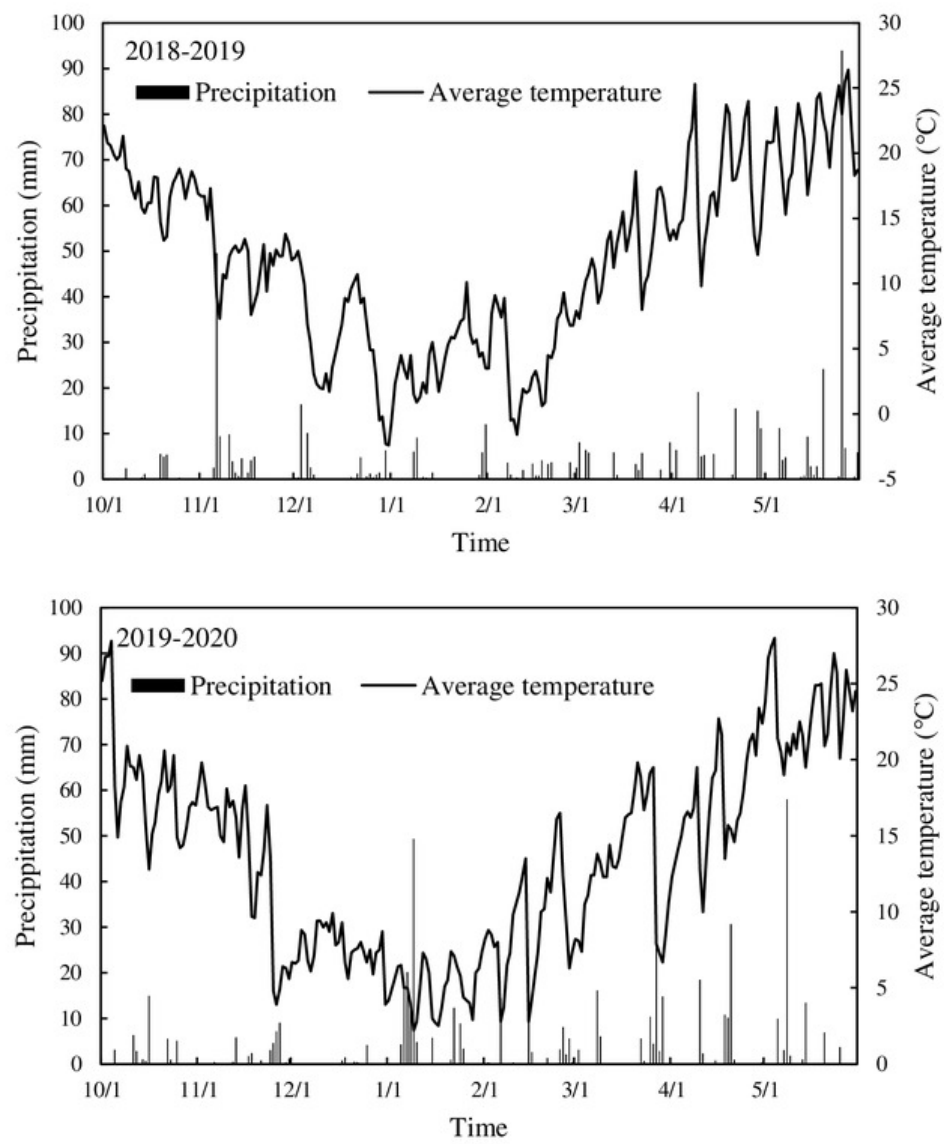
Figure 2

Figure 2 Grain yield loss of winter wheat due to the early and delayed sowing during 2018-2019 and 2019-2020 growing seasons.

Vertical bars indicate standard errors $(n=3)$. 


\section{Figure 2}

Figure 2 Grain yield loss of winter wheat due to the early and delayed sowing during 2018-2019 and 2019-2020 growing seasons.

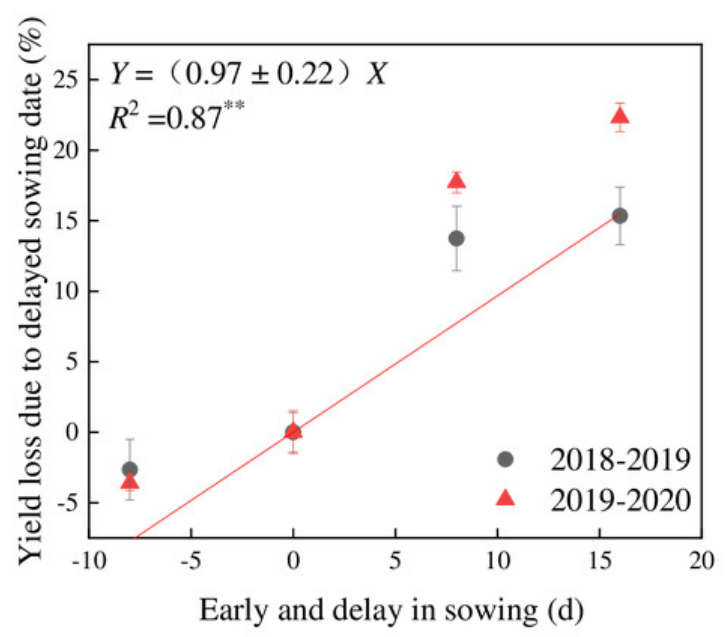


Figure 3

Figure 3 Effects of different sowing dates on DMA for single stem in 2018-2019 and 2019-2020.

Values are means of three replicates per treatment. Vertical bars indicate standard error. 


\section{Figure 3}

Figure 3 Effects of different sowing dates on DMA for single stem in 2018-2019 and 2019-2020.

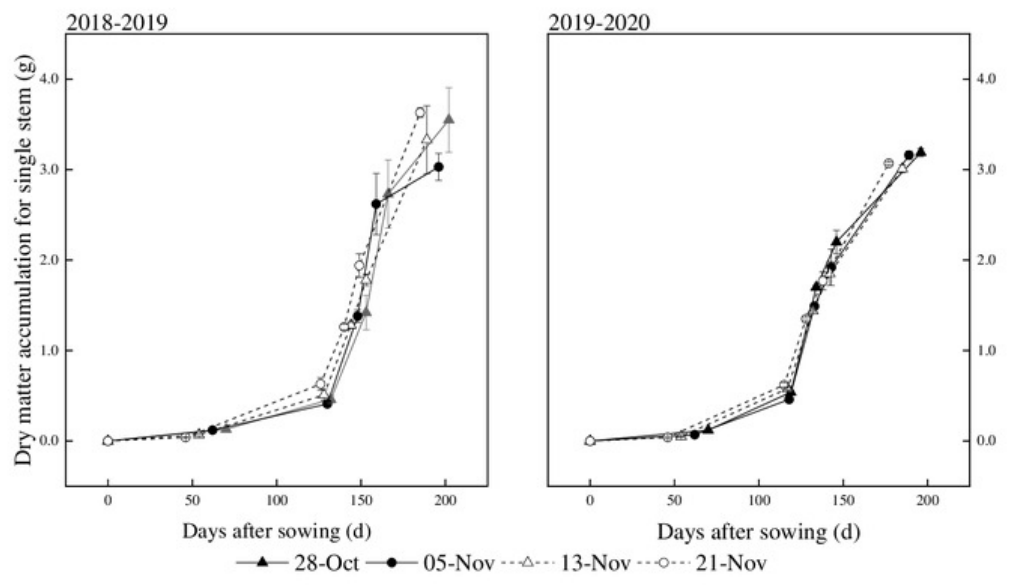


Figure 4

Figure 4 Effects of different sowing dates on NA dynamics for single stem in 2018-2019 and 2019-2020.

Values are means of three replicates per treatment. Vertical bars indicate standard error. 


\section{Figure 4}

Figure 4 Effects of different sowing dates on NA dynamics for single stem in 2018-2019 and 2019-2020.

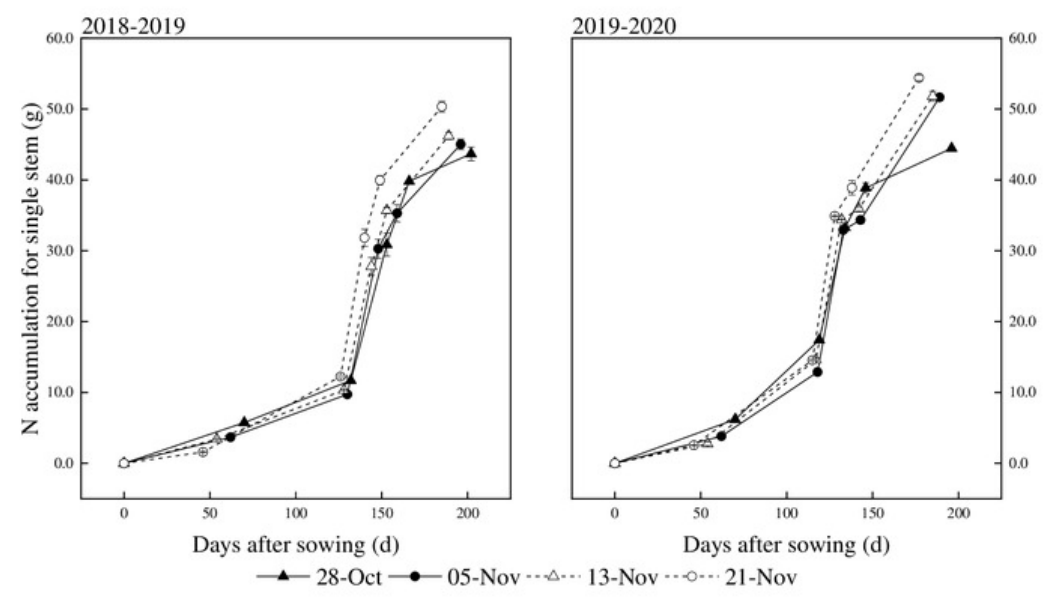


Figure 5

Figure 5 Biomass production and $\mathrm{N}$ production of winter wheat under different sowing date during 2018-2019 and 2019-2020 growing seasons.

Vertical bars indicate standard errors $(n=3)$. Means followed by the same letter are not significantly different among sowing dates according to the $\mathrm{LSD}_{0.05}$ test. 


\section{Figure 5}

Figure 5 Biomass production and $\mathrm{N}$ production of winter wheat under different sowing date during 2018-2019 and 2019-2020 growing seasons.
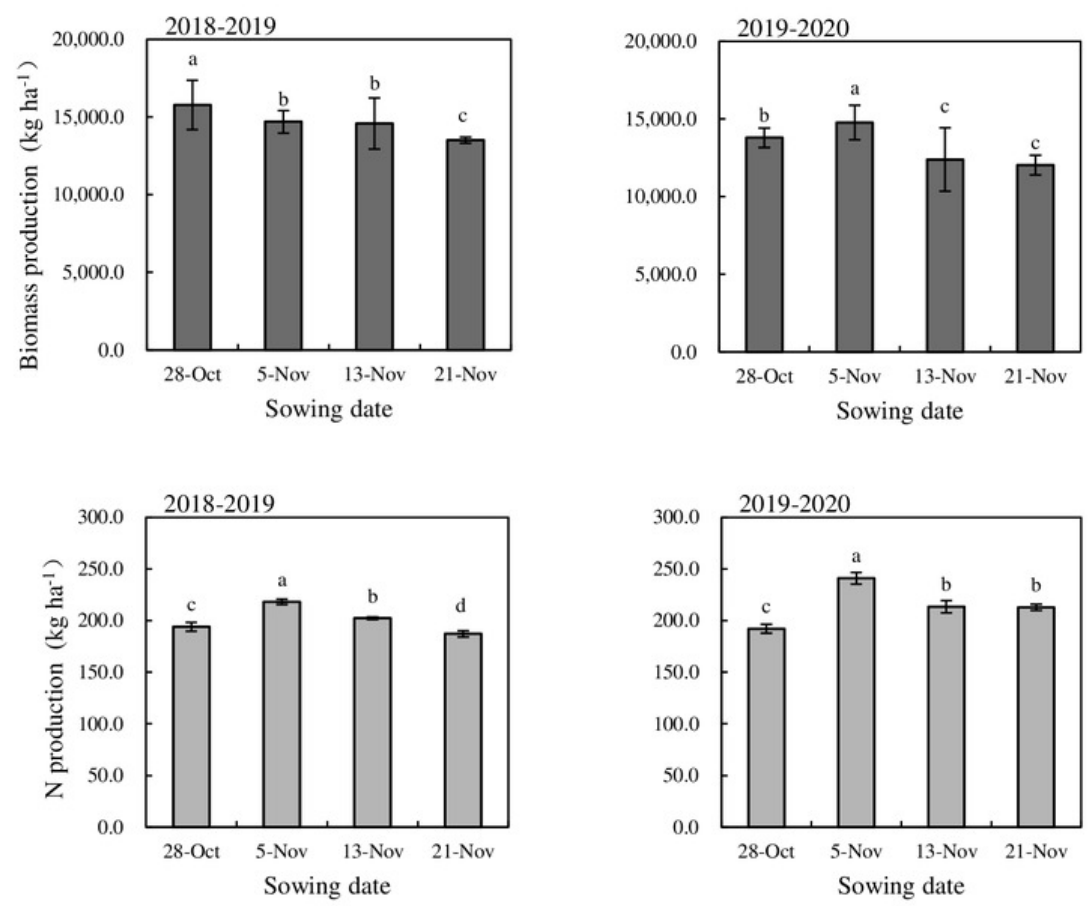


\section{Figure 6}

Figure 6 Relationships between grain yield and four ratios.

(a) the ratio of DMA at maturity stage to jointing stage $\left(\mathrm{M}_{\mathrm{D}} / \mathrm{J}_{\mathrm{D}}\right)$ in 2018-2019 and (b) the ratio of DMA at maturity stage to jointing stage $\left(\mathrm{M}_{D} / \mathrm{J}_{D}\right)$ in 2019-2020 and (c) the ratio of NA at maturity stage to jointing stage $\left(\mathrm{M}_{N} / J_{N}\right)$ in 2018-2019 and (d) the ratio of NA at maturity stage to jointing stage $\left(\mathrm{M}_{N} / \mathrm{J}_{N}\right){ }^{*}$ Correlation coefficients are significant at the 0.05 probability level;

${ }^{*}$ Correlation coefficients are significant at the 0.01 probability level. The shaded part represents the $95 \%$ confidence band. 


\section{Figure 6}

Figure 6 Relationships between grain yield and four ratios.
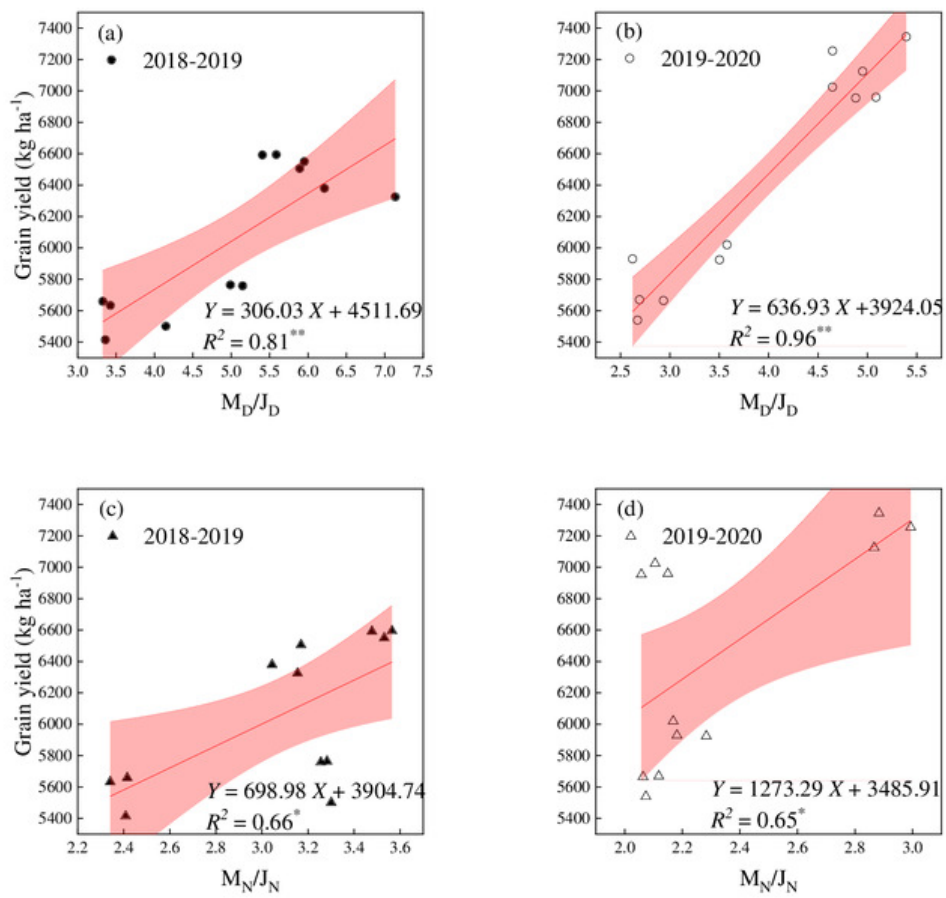